\title{
Har vi råd til å bli gamle?
}

«Ingen skal være redd for å bli gammel,» sa statsminister Jens Stoltenberg i valgkampdebatt på NRK 29.8. 2011. Han fortsatte: «Jeg blir opprørt og berørt når eldre mennesker ikke får den hjelpen de skal ha.» Eller var det Siv Jensen som sa det? Eller var det Christine Sagen Helgø, ordførerkandidat i Stavanger fra Høyre, som deltok i den samme TV-debatten? I forbindelse med kommunevalget 2011 hersker det en forbløffende tverrpolitisk enighet om hva som er galt med eldreomsorgen - og alle hevder at de andre politiske partiene har skylden for det som ikke fungerer. De partiene som ikke sitter med flertallet i en kommune, skylder på dem med makt. De med makt skylder på staten. I Oslo skylder dessuten kommunepolitikerne på bydelspolitikerne og vice versa.

Selv om det finnes mange solskinnshistorier, er det åpenbart at kapasiteten og kvaliteten i eldreomsorgen fortsatt ikke er god nok til tross for at den har vært prioritert av de fleste partier i den ene valgkampen etter den andre. Politikere, pårørende og pasienter er like rystet og uttaler i kor at «slik vil vi ikke ha det i Norge» hver gang mediene viser enda en svekket 90 -åring som ikke har fått plass på sykehjem, avslører at beboere må legge seg klokken fem, at de må dele toalett, at hjemmesykepleierne bruker stoppeklokke eller at ansatte arbeider i ulovlige turnuser. Men det er altså fortsatt slik vi har det i Norge.

Så hva er gjort, og hva kan gjøres? Både økonomiske og juridiske virkemidler er forsøkt. Overføringene til kommunene er økt, det gis investeringstilskudd fra staten til utbygging av omsorgsplasser, og øremerking av driftsmidler til sykehjemmene diskuteres.

Og ikke minst forsøkes såkalt konkurranseutsetting, altså at pleieog omsorgstjenestene settes ut på anbud i håp om at det skal gjøre driften bedre og mer effektiv. De eldre har også fått flere rettigheter, iallfall på papiret: For fire år siden inngikk Arbeiderpartiet, Kristelig Folkeparti og Venstre et eldreforlik med en såkalt verdighetsgaranti. Denne garantien skulle bl.a. sikre de eldre rett til sykehjemsplass når de trengte det. Særlig Arbeiderpartiet har tro på denne garantien og har gjentatte ganger i denne valgkampen oppfordret dem som måtte være misfornøyd med kommunens tilbud om å benytte seg av adgangen til å klage. Men hvor realistisk er det at en eldre pleietrengende vil ha overskudd til å involvere seg $i$ en lang klageprosess?

Problemet er at verken de økonomiske virkemidlene eller «verdighetsgarantien» har hatt ønsket effekt. Det går det an å si med rimelig grad av sikkerhet. Norsk kommunepolitikk kan ses på som et stort eksperiment. Vi har 430 kommuner som styres av mange varianter av politiske koalisjoner. I kommunene har man det til felles at man har lite til overs for sentral styring og stor sans for lokale tilpasninger. De fleste organisatoriske løsninger er forsøkt. Det viser seg at innholdet i pleie- og omsorgstjenestene, ressursbruken og tilfredsheten med tilbudet varierer på kryss og tvers av politiske og geografiske skillelinjer. Og på tvers av løsningene som er valgt. Det er da to mulige forklaringer: Enten at det er en umulig oppgave å få til en eldreomsorg av høy nok kvalitet. Eller at vi ikke har definert presist nok hva problemet er og derfor leter etter løsninger på feil sted.

Behandling, pleie og omsorg er ressurskrevende både med hensyn til penger og personell. Driftsutgiftene til en sykehjemsplass er i dag på $1 / 2-1$ million kroner per år - avhengig av pasientens behov. Mesteparten er lønnskostnader. Selv om ingen er helt sikre på hvor stort behovet for pleie- og omsorgstjenester til eldre blir i årene som kommer - siden vi både lever lenger og er friske lenger - vil ressursbehovet uansett øke fordi antall eldre øker. Statistisk sentralbyrå anslår at vi trenger en dobling av antall årsverk innenfor pleieog omsorgssektoren de neste 30 år. Samtidig endres alderssammensetningen slik at det blir færre yrkesaktive til å gjøre jobben og til å betale for den offentlige velferden over skatteseddelen. Økt etterspørsel etter arbeidskraft kan gi de ansatte høyere lønn, en lønnsøkning som isolert sett er høyst fortjent, men som naturligvis bidrar til å øke de totale utgiftene ytterligere. Hvordan skal dette finansieres? Og er det en grense for hvor høye utgifter de offentlige budsjettene kan bære?

Bakgrunnen for kostnadseksplosjonen er ikke først og fremst ineffektiv drift eller manglende lover og forskrifter. Bakgrunnen er endrede samfunnsforhold og bedre arbeidsforhold for dem som jobber i helsesektoren. Det er ikke så lenge siden at leger jobbet mer eller mindre døgnet rundt (uten spesielt god vaktgodtgjørelse), at sykepleiere fikk dårlig betalt for jobben de gjorde og at kvinnene i familien tok seg av omsorgsoppgavene for både gamle og unge. Slik er det heldigvis ikke lenger. Leger ønsker å jobbe til normale arbeidstider, sykepleiere vil ha skikkelig lønn, og nesten ingen er hjemme for - gratis - å ta seg av familiens gamle og syke. Disse endringene har vi ønsket oss, men de er kostbare - og vi klarer ikke å organisere eller reformere kostnadene vekk. Og selv om det skjer spennende ting innen medisinsk forskning og gjennom utvikling av såkalt velferdsteknologi, vil det først og fremst kunne gi et kvalitativt bedre tilbud, ikke nødvendigvis et billigere tilbud.

Mange later til å tro at vi kan få en «perfekt» helsetjeneste gjennom de rette organisatoriske, juridiske og økonomiske «grep». Men den beste helsetjenesten for en befolkning eller et individ er avhengig av verdier, preferanser og forventninger. Skal vi møte disse forventningene med tilstrekkelig kapasitet, reell valgfrihet og best mulig kvalitet, blir det dyrt. Sannsynligvis så dyrt at det offentlige ikke kan ta hele regningen. Alt tyder på at det er stor betalingsvilje i befolkningen dersom de kunne vært sikret en trygg og god eldreomsorg. Mange betaler allerede en betydelig andel av sin pensjon for offentlige pleie og omsorg, uten å kunne påvirke tilbudet. Kanskje må vi slippe opp på den offentlige styringen og åpne opp for flere styringsog finansieringsmodeller for å sikre et godt velferdstilbud og et likestilt, lovlig og rettferdig arbeidsliv?

\section{Charlotte Haug}

redaktør 